\title{
ANSERJ
}

Vol. 2, No 1

Spring / Printemps 2011

$5-23$

Canadian Journal of Nonprofit and Social Economy Research

Revue canadienne de recherche sur les OSBL et l'économie sociale

\section{Advocacy Limitations on Gender and Sexually Diverse Activist Organizations in Canada's Voluntary Sector}

\author{
Nick J. Mulé \\ York University
}

\begin{abstract}
Registered charities are restricted when engaging in advocacy, whereas Canadian nonprofits face a far more difficult time when fundraising. The impact of such limitations on Canadian gender and sexually diverse ${ }^{1}$ activist organizations is one example of the implications on Canada's democratization process. Despite the efforts of the Voluntary Sector Initiative (VSI), and updated political activity policies, Canada lags behind both the U.K. and U.S. in recognizing and legitimizing advocacy as an important contribution to its democratic process. An organized challenge of the system at the political and legal level is called for to address this issue.
\end{abstract}

\section{RÉSUMÉ}

Les organismes de bienfaisance enregistrés font face à des contraintes lorsqu'ils défendent une cause, tandis que les organismes sans but lucratif rencontrent de nombreuses difficultés pour amasser des fonds. L'impact de ces contraintes sur les organisations militantes de genre et de sexualité diversifiés n'est qu'un exemple de répercussion sur le procédé de démocratisation du Canada. Malgré les efforts déployés par l'Initiative sur le secteur bénévole et communautaire (ISBC) et malgré la mise à jour de politiques sur l'activité politique, le gouvernement du Canada a du retard par rapport à ceux du RoyaumeUni et des États-Unis en matière de reconnaissance et de légitimation de la défense de causes en tant que contribution importante à son processus démocratique. Pour aborder cette question, nous sommes amenés à remettre en question le système de façon méthodique sur les plans politique et juridique.

\section{Keywords / Mots clés}

Activism; Advocacy; Gender and sexually diverse populations; Voluntary sector

Militantisme; Défense d'une cause; Populations de genre et de sexualité; Secteur bénévole 


\section{INTRODUCTION}

This article looks at how Canada regulates the voluntary sector with regard to charitable purpose and political activities in determining charitable status and the ability to advocate for social change. Viewing advocacy as an integral aspect of the concept of charity, I explore how such a premise is aggravated by the doctrine of political purposes. The Voluntary Sector Initiative (VSI) in which the Canadian government engaged in joint talks with the voluntary sector is referenced, and updated political activity policies by the Canada Revenue Agency (CRA) are examined and analyzed. The population focus is specific to Canadian gender and sexually diverse activist organizations, yet the findings have implications across the voluntary sector. Through interviews and content analysis, this paper exposes the limitations placed on Canada's voluntary sector regarding advocacy due to restrictive regulations (Brooks, 2001; Hall et al., 2005; Pross \& Webb, 2003; Scott, 2003; Webb, 2000) and how gender and sexually diverse advocacy groups are disadvantaged regardless of voluntary sector status.

Organized efforts to advocate and lobby for social change in Canadian society on the part of minority and disenfranchised groups in the voluntary sector are limited by regulation (Canada Customs and Revenue Agency, 2003a). The legal status of voluntary organizations (e.g., charitable, or nonprofit incorporated) constrains the extent to which they may advocate or lobby for change. ${ }^{2}$ Although it has been argued that charitable regulations have expanded to include clarification on permitted political activities (Elson, 2007/2008), I contend that these changes represent incremental improvements at best, while limitations persist. Underscoring such limitations is what is termed in the legal literature as the "Doctrine of Political Purposes." This doctrine draws a fine line between political and charitable purposes, deeming the latter ineligible for charitable status if its objects are heavily based upon the former (Parachin, 2008). A critical deconstruction of a series of historical judgments on legal cases of this matter have been critiqued for falling short of legal justification (Brooks, 1983; Carter \& Crawshaw, 1929; Gladstone, 1982; Michell, 1995; Parachin, 2008; Webb, 2000; Wright, 1937), particularly with regard to charities' advocacy work in furthering public benefit (Cotterrell, 1975; Dunn, 2008; Fridman, 1953; Ontario Law Reform Commission, 1996; Parachin, 2008; Sheridan, 1973).

Ultimately, what I bring into question are the limitations placed on charities, and by extension nonprofits, in the voluntary sector. Regulatory constraints concerning political speech and expression based on charitable works limit participation in the political process of democracy (Dunn, 1996). So, why are charitable activities delineated from political purposes such as reforming the law (Dunn, 2008)? This paper is predicated on the role of charity as involved in community engagement and the creation of a civic voice that is permitted to enter the political engagement process on a level playing field, both within the voluntary sector and between sectors (e.g., private sector) as part of a healthy democracy. Such a premise questions why civil society-based organizations that wish to advocate within a social justice mandate are not permitted to do so within the context of registered charity status and its associated benefits.

\section{NONPROFIT ADVOCACY}

Two role dichotomies have been identified within the voluntary sector: an increased role in service delivery, much of it redirected from the public sector; and the role of organizations that challenge the system (government) through social change and associated funding concerns (Lindsay, 2001; O'Connell, 1996). Yet, because there is a voluntary sector dependency on private sector, and particularly public sector, funding of core activities and projects, the level of advocacy activities is limited. This is further exacerbated 
for state "advocacy structures" (i.e., arm's-length governmental bodies) due to a conflict between program effectiveness and repeated program mandate changes by government funders (Malloy, 1999).

Even when there is a delineated difference between the voluntary sector group and the state, partnerships that form between the two create an environment in which advocacy activities become muted. This is due to voluntary sector "community" partners, who are awarded service provision contracts that make them accountable to both service recipients and the state (Basok \& Ilcan, 2003; Walzer, 1995). Voluntary organizations enter contractual agreements that impose restrictive governance (Phillips \& Levasseur, 2004), in essence institutionalizing the relationship with negative implications on advocacy and autonomy (Laforest \& Phillips, 2001). The subsequent impact is one in which actors within the voluntary sector increasingly become overly responsible service providers at the expense of being advocates for social justice (llcan \& Basok, 2004; Laforest \& Orsini, 2005).

Some such actors form collective identities representing agreed-upon interests, creating political agencies that counter dominant groups and political discourse (Jenson, 1993, 1995; Kymlicka, 1996). Such collective voices demand a form of citizenship that includes not only benefits but also a right of representation both to and by the state (Jenson \& Phillips, 1996). The gender and sexually diverse populations have formulated such groups in Canada, with many having attained charitable status. Historically, Canadian lesbian and gay activists have had to carefully weigh their strategies between philosophical leanings and pragmatic achievements (Adam, 1995; Rayside, 1998; Ross, 1995; Warner, 2002). Regardless of which strategies are chosen, the concept of explicit representation (Jenson, 1995) is an important one to the gender and sexually diverse movement (Mulé, 2006; Smith, 2005a), reflected in the demand for infused recognition in policy (Mulé, 2005).

Distinct from the legal justice of human rights protections for lesbians, gays, and bisexuals-yet still absent for transsexuals, transgenders, and intersex ${ }^{3}$-there is much to focus on with regard to social justice for all these populations (Kinsman, 1987, 2006; Mulé, 2006; Smith, 1999; Warner, 2002). The legalization of same-sex marriage and the right to adopt can create a false impression of "equality," particularly when the gender and sexually diverse face and experience numerous social justice issues. These social justice issues include bullying and bashings, stigmatization and low self-esteem, and employment barriers; STIs such as HIVIAIDS; and broad health concerns such as depression, substance use, addictions, and risk of suicide. Intersectional concerns may be age-based, involving children, youth, adults, and seniors who identify as lesbian, gay, bisexual, or transgender (LGBT); ethno-racial cultural conflicts; (dis)ability challenges; and religious-based crises.

The current neoliberal environment discourages local gender and sexually diverse organizations from engaging in advocacy activities, creating a focus on service provision (Carroll \& Ratner, 2001; Smith 2005a, 2005b). The gender and sexually diverse movement at the federal level has taken a legal approach, reinforcing individualism and class politics in line with neoliberalism (Smith, 2005b). Thus, despite legal recognition for some, ${ }^{4}$ the specified and particularized needs of the gender and sexually diverse communities from a social justice perspective continue, and as such full citizenship in civil society remains elusive (Sears, 2005). Social justice work by NGOs is often hampered by capacity concerns (Laforest \& Orsini, 2005) of which gender and sexually diverse social justice groups are not exempt, operating in under-resourced environments in terms of funding, personnel, volunteers, and time. This can have a negative impact on their capacity to address policy concerns in a timely and appropriate fashion. This neoliberal environment, coupled with a history of oppression and disenfranchisement (Adam, 1995; 
Smith, 1999; Warner, 2002), has resulted in a systemic lack of recognition in policy (Mulé, 2005, 2007), reinforcing the marginalization of gender and sexually diverse populations.

Critical social work theories (Fook, 1993; Moreau, 1979, 1990; Moreau \& Leonard, 1989; Mullaly, 2007) recognize the dialectical relationship between the state and its structures with individuals and their communities in that both benefits and oppression can be experienced (Allan, 2003; Pease \& Fook, 1999). On the one hand there is the attainment of recognition (via charitable and/or nonprofit incorporated status) to address a social issue via service delivery. On the other hand there is the frustration of not being able to address the "causes of the causes" due to limited advocacy opportunities. Specific to gender and sexually diverse populations, queer liberation theory (Altman, 1971; Bronski, 1998; Vaid, 1995; Warner, 1999; Warner, 2002) speaks to agency utilized by individuals and organized social movements that recognizes, respects, and dignifies their difference as a valid contribution to the diversity of society, contributing to a project of emancipation as undertaken by progressive members of the LGBT communities. This liberation strategy is distinct from the norm within the membership of the LGBT communities who are inclined to work within structured systems toward neoliberalized notions of acceptance and respectability (Duggan, 2003; Richardson, 2005) and are thus far less inclined to question such systemic structures and their implications on cultural diversity (Mulé, 2006, 2008). A fused critical queer liberation and critical theory lens identifies limitations, questions the status quo, and seeks systemic change through emancipation. Premised on such a lens, what is the impact of existing CRA policies on advocacy/political activities on charities, and by extension, nonprofit civil society organizations such as those in gender and sexually diverse communities?

\section{METHODOLOGY}

Data gathered for content analysis in this study targeted existing policies, standards, and guidelines reviewed from a structural systemic perspective inclusive of current regulations on the Canadian voluntary sector particular to advocacy, political activities, and recognition of diversity in Canada between April 2001 and May 2010. The Internet served as a major source in the gathering of these data. This critical discourse analysis focuses on interviews conducted with leading Canadian gender and sexually diverse social justice organizations and how they are implicated by the regulation of Canadian charities. ${ }^{5}$

\section{"ADVOCACY" AND THE CONCEPT OF CHARITY}

At the core of the relationship between charity and social justice is the legitimacy of advocacy activities. The extent of advocacy activity by charities has been historically and legally restricted based on the doctrine of political purposes. What is argued in this paper is that if charities are to effectively address their mandates they must take on the "causes of the causes" that frustrate their ultimate purpose, and this requires the ability to advocate for social reforms. By placing advocacy restrictions on charities, their work is often reduced to service provision, and the capacity to affect the social changes required to adequately address the very issues the charity has been created to address is lost. Thus, I will argue that restricting nonpartisan advocacy is antithetical to a charity's capacity to fully carry out its good works.

From a legal perspective, the doctrine of political purposes has enormous influence on this issue, establishing the principle that advocacy activities by charities are incongruous. Doctrine arguments are based on tradition and legal authority, the incapacity of the judiciary to rule on public benefit as derived from political purposes (Drassinower, 2001), and the ascription of differentiation between charity and politics (Parachin, 2008). Such arguments conceptualize charities as needing, for the most part, to 
separate themselves from political matters. Political matters are often controversial, as though charities and their good works are incompatible with controversy (Harvie, 2002; Sacks, 1960). The very essence of issues experienced by the gender and sexually diverse communities has been seen by many as political and controversial, yet these communities are not alone in the voluntary sector as being deemed as such.

What is posited here is a concept of charity that permits nonpartisan political activity involving advocacy that is in keeping with a charity's purposes. This argument is premised on the principle that, based on the importance and relevance of their work, charities have a valuable voice to contribute to society through the democratic process. Placing advocacy restrictions on such charities, regardless of their mission or where they are positioned on the political spectrum, limits their freedom of speech and expression, and curtails their ability within the democratic process to reform law (Dunn, 1996, 2008) or engage in influencing social change.

\section{CRA POLICIES}

In 2003, the CCRA implemented a new policy statement, Political Activities, that defines advocacy as, "demonstrated support for a cause or particular point of view. Advocacy is not necessarily a political activity, but it sometimes can be" (CCRA, 2003a, p. 15). Political purposes in this policy is based on the legal definitions, "to support a political party or candidate for public office; or to seek to retain, oppose, or change the law or policy or decisions of any level of government in Canada or a foreign country" (CCRA, 2003a, p. 16). The policy extends to political activities, giving charities more leeway in conducting public awareness programs. This includes explicit communications, calls for political action, and intentions of activity toward retaining, opposing, or changing a law, policy, or decision at any level of the Canadian government or a foreign country (CCRA, 2003a). Also, this policy implemented a sliding scale of expenditures for political activities ranging from $10 \%$ to $20 \%$, based upon revenue levels of charitable organizations. Charities with revenues in excess of $\$ 200,000$ are capped at $10 \%$ and otherwise vary with income down to the lowest category (less than $\$ 25,000$ ) at 20\% (CCRA, 2003a). This change contrasts with the previous across-the-board $10 \%$ expenditure limit.

The CCRA subsequently issued a policy statement Registering Charities that Promote Racial Equality (CCRA, 2003b) that essentially broadens the definition of charitable purposes to include organizations that promote or educate about racial equality, work to eliminate racial discrimination, and foster positive race relations in Canada. Thus, the promotion of racial equality is now recognized by the CRA as analogous to mental and moral improvement, which falls under the fourth charitable purpose of "other purposes beneficial to the community." Organizations could also qualify under the purpose of "advancement of education." The rationale provided in the policy for this expansion cites both U.K. and U.S. policies, but selectively zeroes in on race relations issues, ignoring the broader anti-discrimination policies that exist in both countries. More recently, the CRA issued another guidance document, Upholding Human Rights and Charitable Registration (2010), in which upholding human rights is considered charitable under all four heads (see above) and can be considered a charitable purpose in its own right under the fourth head, "other purposes beneficial to the community that are considered charitable at law." At the outset, this guidance appears to be more comprehensive than the more specified focus of "promoting racial equality," yet it too has its limitations.

Three gender and sexually diverse organizations in Canada, each operating with different nonprofit models, offer insights into how they function under voluntary sector regulations. Their respective mandates and means of pursuing social justice for the gender and sexually diverse dictated which model 
each settled for in order to meet their purposes. Egale Canada is a national multi-issue LGBT rights nonprofit organization, which set up a charitable arm to allow it to pursue its advocacy work under the former and public education work under the latter in order to reap the benefits of the charity system. This model notwithstanding, the restrictions on advocacy are no less felt:

I mean it's-obviously it's a headache. And it's an administrative headache, in terms of having to run parallel organizations when you have limited resources. So, there are huge issues with respect to it. And the tax receipts, the filing, the administrative stuff is a nightmare ... It restricts what we can do as an organization ... Because when you want to raise money for a court case, people don't get a tax receipt, and a lot of people donate because of tax receipts ... It takes us away from our advocacy work, because we constantly have to figure out where we're going to get our next dollar in order to advance LGBT rights ... So, I think it's another way of tying our hands, with respect to advocating for LGBT rights in Canada ... we're certainly not given any encouragement or help from government in advancing human rights. (Egale Canada Representative, September 9, 2010)

The Canadian Rainbow Health Coalition (CRHC), also a national LGBT rights organization with a focus on the broad health and well-being issues of these populations, sought and received registered charity status. From its process in attaining such status to its ability to carry out its purposes, the role of advocacy has been impacted:

[O]ne of the problems that we ran into initially was in our application for charitable status with Revenue Canada. We had to end up changing some of our purposes to remove terms like "advocacy," so we had to change that to "educate" in order to get our charitable tax status ... Certainly it affected the language and in some ways it seemed to me to be a little petty to change the word "advocate" to "educate," to basically say the same thing, just a change of word ... the problem we had around our mandates and mission statements with Revenue Canada certainly delayed us getting charitable tax status so that was problematic ... It certainly causes us to be careful about the advocacy work we do I mean, certainly, when we're dealing with government, and I think that we've tried to do a bit of advocacy with Health Canada and the Public Health Agency of Canada to again get them to address the health issues. And there are Revenue Canada's rules that one has to be careful around the amount of lobbying that they do, certainly political lobbying or what they consider to be political lobbying ... I think at times that they're problematic. We work with our community to solve our own issues; but governments at all levels also have the responsibility to address our populations' issues, so I think at times the [political activity] rules have the capability of hamstringing organizations. (Canadian Rainbow Health Coalition Representative, May 22, 2009)

The provincially based Queer Ontario (successor to the now dissolved Coalition for Lesbian and Gay Rights in Ontario [CLGRO]) is a multi-issue progressive, radical nonprofit group that advocates for LGBTQ Ontarians' rights. Strong adherence to their mandate for advocacy and political activities have caused CLGRO/Queer Ontario to question how the voluntary sector is structured and critique the inherent limitations placed on social justice groups: 
You see this is how groups such as our predecessor CLGRO and our current entity Queer Ontario came to the decision to be nonprofit organizations and not formally seek charitable status. These organizations both had "advocacy" right in their respective mission statements. Both were and are highly principled organizations that are strongly committed to their goals and values. We always had a strong sense then, when we were CLGRO, and even now as Queer Ontario, that we will not compromise on advocating for the rights of LGBT people from a progressive queer perspective. Thus, we were not prepared to reshape ourselves to fit governmental regulations at the expense of our work. Now, this is not to say the consideration of becoming a charity wasn't taken up, because it was within CLGRO but ultimately not pursued because it was apparent our mission statement would raise red flags with CRA. It was at this point that CLGRO started raising questions about the system. Why is advocacy, or does advocacy raise alarm bells for the government? Why would fighting for the rights of LGBT people in Ontario not be seen as charitable? Is this not a human rights issue? Why are human rights issues not a concern? (Coalition for Lesbian and Gay Rights in Ontario/Queer Ontario Representative, October 3, 2010)

As is further discussed in the next section, the intricacies and nuances of Canada's charity policies maintain a conservative ideology that does not necessarily embrace change. It can at minimum contain, if not outright constrain, the progressive dynamic voices of its voluntary sector, regardless of whether those voices are coming from the conservative or liberal ends of the political spectrum, as all are restricted by the doctrine of political purposes affecting the sector.

\section{DISCUSSION}

Operating from the premise that the voluntary sector (and the varying organizations therein: charities, nonprofits, etc.) has an important role to play in contributing to social justice, critical social work theory calls on actors in civil society to be accountable to those whom they serve (Dominelli, 1997; Fook, 1993; Mullaly, 2002). Such accountability is not reserved for service provision only, but includes addressing systemic and structural issues that can create and perpetuate social injustices for individuals and communities (Carniol, 2010; Adams, Dominelli, Payne, 2009; Mullaly, 1998). This is a deeper level of accountability that goes beyond merely tending to the symptoms of social problems known as "band aid solutions" and getting to the root of issues known as the "causes of the causes" via advocacy for social change.

Yet, it is precisely at this juncture that the values of social justice conflict with current CRA policies. Social justice, which values fairness, equality, equity, dignity, and diversity, for example, is not always aligned with the parameters of legal justice. This is not to say the pursuit of social justice (i.e., human rights) is uncontroversial, but rather part of the role of civil society in a democracy is to identify, raise, and educate about such issues and to grapple with them as a charitable purpose that will ultimately benefit society. Canada's parliamentary democracy neither facilitates nor encourages political activism, particularly when compared to the U.S. republican democracy (Belfall, 1995). The structural apparatus that underpins the voluntary sector, in essence, restricts the extent to which charities may undertake advocacy activities. By extension, the resources of nonprofits are restricted as they cannot issue tax receipts for donations, negatively implicating their ability to fundraise. 
These systemic limitations are of particular relevance to the gender and sexually diverse communities who only attained legal recognition in human rights legislation based on sexual orientation (Adam, 1995; Smith, 1999; Warner, 2002) over the past 35 years in Canada but are still pursuing gender identity rights. Long-fought advocacy achieved these legal victories, but now with most human rights battles having been won on the legal justice front, there are many more challenges on the social justice front. Complicating these challenges is the observation that the gender and sexually diverse communities are non-monolithic. Queer liberationists (e.g., Queer Ontario) are considered the most progressive segment of the gender and sexually diverse communities for their discontent with the status quo, their challenging of heterosexist hegemony, and their demand for recognition and legitimization based on difference. As such, advocating for a liberationist type of social justice within a larger neoliberalized gender and sexually diverse community (Duggan, 2003; Richards, 2005; Smith, 2005b)—Egale Canada, for example-that seeks acceptance, respect, and the opportunity to assimilate (hence working with the system) proves challenging (Mulé, 2006) for queer liberationists. The latter find themselves contesting the very political activity restrictions the CRA outlines by undertaking such social justice advocacy.

Although the federal government is slowly broadening its interpretation of the four heads of charity, and particularly of purposes beneficial to the community, the CRA's means of doing so continues to be conservative and restrictive. The 2003 policy document Registering Charities that Promote Racial Equality (CCRA) was curious in that this commendable guidance was nevertheless limited to the one social location in the absence of so many others in multicultural Canada. What underscores the design and development of this policy is an implicit ideologically driven heterosexist discourse that fails to acknowledge or recognize gender and sexually diverse populations. It would be another seven years before the CRA would issue its document Upholding Human Rights and Charitable Registration (2010). In both cases the jurisdictions of the U.K. and U.S. are cited as having similar policies and in both cases the CRA was selective in what it chose to highlight.

Given that legal precedent establishes that charitable purposes are premised upon the formal policy acknowledgment of an accepted public benefit, and that generalized anti-discrimination work and the promotion of human rights has been accepted as such in the U.K. and U.S., Canada's initial restricted focus on anti-racism and its more recent and conservatively named Upholding Human Rights and Charitable Registration (CRA 2010) could better reflect the breadth of Canadian human rights legislation (ILGA, 2000) and its potential for expansion (CCEW, 2002a, 2003b; CCRA 2003a, 2003b; Charity Commission News, 2003; IRS, 2002). Both of these policies place a heavy emphasis on upholding existing law, underscoring the limitations on its Political Activities policy (CCRA, 2003a) that charities operate under. In addition, a review of the permissible purposes and activities of the aforementioned two policies emphasize education/service provision, preaching, research and analysis, and public awareness as acceptable. Although these activities do verge on advocacy, charities cannot explicitly pressure the government to enact or alter legislation.

The CCRA's Promotion of Racial Equality policy document (2003b), with its named sole focus on the elimination of racial discrimination, falls short of, and thus is contradictory to, the broader parameters of Canadian human rights legislation. For example, opposing homophobia and heterosexism would also be conforming to existing laws, yet this is explicitly absent from this policy. The CRA's Upholding Human Rights and Charitable Registration (CRA, 2010) expands the terrain to include other minorities such as the sexually diverse (e.g., lesbians, gays, and bisexuals). However, this policy's implicit stance of providing a public benefit based on existing law excludes minorities who are not legally protected from discrimination. Therefore, minorities based on gender identity, such as transsexuals, transgenders, and 
intersex, would fall outside the purview of this policy given their lack of protection in Canadian human rights legislation.

The representative system in Canada, contrary to both the U.S. and U.K., has not adapted to interestfocused groups and their representation in the democratic process (Pross, 1986). Given this, how do voluntary sector regulations ensure that all charitable purposes are respectful of Canadian human rights legislation? It would be beneficial if the CRA adopted what the U.S. and the U.K. currently have. Both countries include definitions in their charitable purposes that broadly address discrimination and promote human rights, domestically and abroad, as a valued contribution to democracy and social development. And although the U.K. and U.S. also have similar limitations on political activities, the iteration of their respective policies is not nearly as constrictive. The CRA's Upholding Human Rights and Charitable Registration (2010) focuses on the limits rather than the potential achievements of the policy.

In Canada, advocacy legitimacy is based upon tax rules rather than broader principles of democracy, resulting in an unclear concept of advocacy premised on highly restrictive court definitions (Phillips, 2003b). Yet it is noteworthy that the CCRA made an attempt to expand both its definition of permissible political activities and its corresponding expenditure limits (CCRA, 2003a). The former contributes to a clearer understanding of the extent to which charities may engage in advocacy work involving political activities and the latter is an attempt at levelling the internal field of charities with regard to resource expenditures of larger versus smaller charities. Although this policy provides some degree of clarification regarding political activities, its impact is rather limited in the absence of an expanded definition of charitable purposes. A mathematical calculation of the expenditure limits reveals a valiant attempt at addressing the imbalance of influence based on the size of charitable organizations, but one with limited success as larger charities are disproportionally advantaged.

The attempts of CRA to further clarify what is and is not permissible for charities to engage in regarding human rights, political activities, and thus advocacy can be described as meagre at best, for such policies continue to be undermined by the persistence of the doctrine of political purposes. A doctrine has been developed through the courts over the past few centuries based on a series of legal test cases on the role of political purposes, often conflated with advocacy, in the work of charities. Attempts at distinguishing charity and politics (i.e., partisan versus nonpartisan politics, political activities, lobbying, advocacy, and influencing the public) via jurisprudence have been found to be inconsistent, with some cases being superficially justified and others historically inaccurate (Parachin, 2008). The rationale for this doctrine includes being a time-honoured practice, the authority of the law as it currently stands, judicial incapacity to rule on public benefit derived from political purposes (Drassinower, 2001), and charity and politics being described as merely "just different" (Parachin, 2008). Although the doctrine allows for a certain amount of political activity, what remains elusive to charities is the indeterminate line at which such activity no longer is permissible. This dilemma is further complicated by the asserted incompatibility of charity and controversy (Harvie, 2002; Sacks, 1960). The inconsistency of the doctrine of political purposes completely negates the reality that for some charities controversy will be at the core of their purposes. This issue also intersects with the concept that promoting a point of view is political while the advancement of religion is charitable and the tension that lies therein (Parachin, 2008) is only mentioned here as this issue is much greater than the purposes of this paper.

\section{Advocacy and the LGBT movement in Canada}

The Canadian Rainbow Health Coalition, Egale Canada, and Queer Ontario are three of a limited number of gender and sexually diverse organizations that take up political advocacy work, and as such they are 
at the forefront of the LGBT movement in Canada. These three gender and sexually diverse organizations each operate under different models within the voluntary sector. The Canadian Rainbow Health Coalition sought and obtained charitable status, but not without having to revise the iteration of its mission and having to closely monitor its advocacy activities as a result. Egale Canada essentially runs as two organizations, one of which is established as a registered charity. This not only doubles the administrative work and limits its focus on advocacy, but also requires it to closely self-monitor the activities that are advocacy based so as not to attract suspicion about its purposes.

Queer Ontario quite consciously opted to be a nonprofit organization due to advocacy being an integral part of its mission, and based on its predecessor's (CLGRO) work on the issue both internally and to a limited extent within the VSI (see earlier CLGRO/QO quote). Yet Queer Ontario operates on a very limited budget due to this decision. In essence, what is revealed here is that regardless of their operational models, all three are experiencing limitations in being able to fully carry out their respective mandates involving advocacy work. The implications for the progress of the gender and sexually diverse movement are concerning. Although the limitations expressed can be extrapolated to other social justice movements within the voluntary sector, for the gender and sexually diverse their general oversight and awkward referencing during the VSI (VSI, 2002a) and resulting CRA policies (CCRA, 2003b; CRA, 2010) demonstrate an ongoing sense of not being fully recognized.

Analytically, the themes of power imbalances to cultural repression, from discriminatory privilege to subjective politics and systemic bias, both within the voluntary sector and its regulators are worthy of closer examination in four contexts. First, the limitations inherent in Promotion of Racial Equality (CCRA 2003b), and the way the VSI structured and referenced racial and cultural groups, both excluded numerous other groups protected by Canadian human rights legislation. Second, the non-recognition of lesbians, gays, and bisexuals as a cultural group defined by sexual orientation is culturally repressive and limiting. Third, ignoring legally unprotected gender minorities such as transsexual, transgender, and intersex people sets up a systemic bias based upon privilege (CRA's 2010 Upholding Human Rights and Charitable Registration). Lastly, by focusing narrowly on definitions of racism and racial discrimination (CLGRO, 2003) or upholding current human rights laws, these policies undermine the experience of inequality felt by numerous minority groups and individuals with intersectional minority status. In essence, the kind of barriers gender and sexually diverse populations face in general society is mirrored in the voluntary sector's review and current structure. Ultimately, this can hinder attempts at reducing homophobia, transphobia, and heterosexism in Canadian society.

To be adequately heard within Canada's democratic society, gender and sexually diverse communities require the capacity to advocate on a level playing field. This lack of capacity is reflected in the absence of a formal concerted voice coming from gender and sexually diverse communities across Canada. Although Egale Canada had identified the Voluntary Sector Initiative as an issue (Egale Canada, 2003), it did not take any formal steps to address its concerns at the time, partly due to a preoccupation with attaining same-sex marriage rights. CLGRO, because of its limited resources, was only able to monitor the VSI process, make submissions to the CRA's 2003 proposals on political activity and the elimination of racial discrimination (CLGRO, 2003), and host a community forum. CLGRO has since dissolved and its successor Queer Ontario (2010) lists advocacy and activism within the voluntary sector as one of its numerous concerns:

[P]eople are not fully aware of the complexities of the voluntary system and how it works, including people within the LGBT communities.... This speaks to the kind of 
in-depth analytical processes CLGRO would engage in, that many other LGBT groups didn't. It's why we became interested in the process of the Voluntary Sector Initiative (VSI). Even there, had we the resources to contribute more time and attention to it, we would have, but ultimately we only provided feedback on guidelines CRA produced in the midst of the VSI and we also hosted a public forum in our communities on the issue. And as it turns out, even that limited input on our part, turned out to be the only input from an organized LGBT body, as far as we know. (Coalition for Lesbian and Gay Rights in Ontario/Queer Ontario Representative, October 2, 2010)

Because of how charities are regulated, efforts to change laws and/or government policies and influence public behaviour and community opinion, on the part of all of its actors, is highly controlled and restricted (IMPACS, 2001b; IMPACS \& CCP, 2002). This restrictive atmosphere keeps registered charities and the people they serve systemically oppressed. The lack of recognition of gender and sexually diverse populations within broader voluntary sector policy only further silences their voices and limits their impact in affecting social change outside the courts. Even beyond gender and sexually diverse populations, the current Conservative government has created a hostile environment for organizations that engage in advocacy work (Brennan, 2010; Ward, 2010).

\section{Implications for the voluntary sector}

The current political environment is an unfortunate one for the broader voluntary sector as it will require political will at the federal level to address the changes required to better acknowledge the importance of advocacy in the work of the sector. The limiting effects on advocacy work undertaken by the gender and sexually diverse communities can be extrapolated to the voluntary/nonprofit sector at large. Although the Panel on Accountability and Governance in the Voluntary Sector, under chair Ed Broadbent, brought this issue to the government's attention and CRA policies were subsequently updated to reflect broader policy changes, no federal party has taken up the explicit issue of advocacy and its limitations in the voluntary sector (Panel on Accountability and Governance in the Voluntary Sector, 1999).

Legally, charities have been generally conceptualized as separate from advocacy and associated political activities as argued in the doctrine of political purposes (Parachin, 2008). Challenges to these legal constraints are required - with the plural emphasized-as some specific cases have done just that (see Parachin, 2008). Clearly more is required if the broader legal context is going to shift. A major disadvantage to nonprofits without charitable status is their inability to raise funds in the absence of "credibility" that comes with being a charity. What will instigate such changes will be a collective voice of charities and nonprofits within the voluntary sector that are most directly affected. Ideally, a collaborative effort on the part of the major sectors (public, private, and nonprofit) could encourage a concerted change, yet this scenario is highly unlikely given differing interests and losses that would be felt by some in levelling the field. The most affected organizations (recognizing that not all are affected) will need to organize and inform themselves, then strategize on how and where to call for a reconceptualization of charities and nonprofits that see the value and importance of advocacy as an integral and indispensable part of their work for social justice within Canada's democratic system.

\section{CONCLUSION}

Although several attempts have been made to modernize the voluntary sector in Canada, this study found that the designation of charitable purpose, the lack of definition of "advocacy," and what is 
considered permissible political activity restricts both registered charities and nonprofits in their participation in policymaking. Contributing to these restrictions is how the registered charities are regulated under the Income Tax Act and an adherence to the doctrine of political purposes.

Furthermore, this paper's focus on gender and sexually diverse activist groups, as one example of a social justice-seeking constituency, with mandates of social change, found that regardless of status, they were all negatively affected by advocacy regulations. Shortcomings were found in the CCRA's Promotion of Racial Equality policy (2003b), which simultaneously highlights redressing one form of discrimination and oppression while omitting all others. This stand contradicts Canadian human rights legislation and the CRA's recent (2010) Upholding Human Rights and Charitable Registration policy.

The price paid for silencing minority and disenfranchised groups is that some of the most informed voices on social issues are not being permitted to participate on a level playing field with their public and private sector counterparts. This denies Canadian citizens the resourceful breadth and depth of knowledge that the voluntary sector can offer in policymaking processes. A reconceptualization of charity and the systemic approach to nonprofits is required at the political and legal level, spearheaded by grassroots organizations within the voluntary sector, to challenge current restrictions on advocacy and the detrimental effect on social justice.

\section{NOTES}

1. For the purposes of this paper, gender and sexually diverse populations refers to individuals who identify as lesbian, gay, bisexual, transsexual, transgender, two-spirit, intersex, queer, and/or questioning.

2. To be deemed a charity, an organization must apply for such status through the regulating body of their respective country. Charitable status allows the organization to issue tax receipts for donations received, resulting in higher fundraising returns and qualifying them for public funds by numerous funding bodies that require such status. Yet, charities are restricted in the degree to which they can engage in advocacy or lobbying activities. Nonprofit organizations are not under charitable regulations and thus are free to undertake advocacy and lobbying activities to the extent they choose. Yet, these organizations cannot issue tax receipts for donations received and have limited options for public funds, and thus have greater difficulty sustaining themselves.

3. A federal bill that would have provided explicit human rights protections including against hate crimes based on gender identity and gender expression, got as far as the Senate, but died before being voted on due to the 2011 federal election call.

4. Sexual orientation has been included as a prohibited ground for discrimination in human rights legislation federally in Canada since 1995 and in all provincial and territorial human rights legislation throughout the country.

5. Interviews with government officials were conducted for the study but have not been utilized in this analysis.

\section{REFERENCES}

Adam, B.D. (1995). The Rise of a Gay and Lesbian Movement (2nd Ed.) Boston: Twayne.

Adams, R., Dominelli, L. \& Payne, M. (2009). Critical Practice in Social Work. Basingstoke: Palgrave MacMillan.

Allan, J. (2003). Theorizing critical social work. In J. Allan, B. Pease \& L. Briskman Critical Social Work: An Introduction to Theories and Practices, Crows Nest, NSW: Allen \& Unwin, 52-72.

Altman, D. (1971). Homosexual Oppression and Liberation. New York: Outerbridge \& Deinstfrey. 


\section{Mulé (2011)}

Basok, T. \& Ilcan, S. (2003). The voluntary sector and the depoliticization of civil society: Implications for social justice. International Journal of Canadian Studies, 28, 113-131.

Belfall, D. (1995). Associations in Canada: Future Impact and Influence. Toronto: Foundation for Association Research and Education.

Brennan, R.J. (May 5, 2010). We won't shut up, women tell PM. Toronto Star, A1, A12.

Bridge, R. (2000). The Law of Advocacy by Charitable Organizations: The Case for Change. Vancouver: Institute for Media, Policy and Civil Society.

Brock, K.L. (2004). The devel's in the detail: The Chretien legacy for the third sector. Review of Constitutional Studies, 9(1\&2), 263-282.

Brock, K. L. (2005). Judging the VSI: Reflections on the relationship between the federal government and the voluntary sector. The Philanthropist, 19(3),168-181.

Brock, K.L. (forthcoming). A comprehensive Canadian approach to the third sector: Creative tensions and unexpected outcomes. In B. Gidron and M. Bar (Eds.), Policy initiatives towards the third sector in international perspective, nonprofit and civil society studies.

Bronski, M. (1998). The liberation of pleasure in Bull, C. (2001). Come Out Fighting: A Century of Essential Writing on Gay \& Lesbian Liberation. New York: Thunder's Mouth Press/Nation Books, pp. 299-302.

Brooks, N. (1983). Charities: The legal framework. Ottawa: Secretary of State.

Brooks, N. (2001). The role of the voluntary sector in a modern welfare state. In J. Phillips, B. Chapman \& D. Stevens (Eds.), Between state and market: Essays on charity law and policies in Canada, (pp. 166-216). Montreal \& Kingston: McGill Queens University Press.

Cabinet Office, Performance and Innovation Unit, Voluntary Sector Team. (2001). Campaigning and Political Activities of Charitable and Voluntary Organizations. URL: http://www.strategy.gov.uk/2001/charity/attachments/Politicalactivities.pdf [February 24, 2002].

Cabinet Office, Strategy Unit. (2002). Private Action, Public Benefit: A Review of Charities and the Wider Not-For-Profit Sector. URL: http://www.strategy.gov.uk/2002/charity/report/downloads/strat-data.pdf [November 8, 2002].

Canada Customs and Revenue Agency. (2003a). Policy Statement: Political Activities. URL: http://www.ccraadrc.gc.ca/tax/charities/policy/cps-022-e.html [November 6, 2003].

Canada Customs and Revenue Agency. (2003b). Policy Statement: Registering Charities that Promote Racial Equality. URL: http://www.ccra-adrc.gc.ca/tax/charities/policy/cps-021-e.html [November 6, 2003].

Canada Revenue Agency (CRA). (2010). Upholding Human Rights and Charitable Registration. URL:

http://www.globalphilanthropy.ca/index.php/blog/comments/cra_releases_its_guidance_on_upholding_human_rights_and_cha ritable_registra [November 5, 2010].

Carniol, B. (2010). Case critical: Social Services and Social Justice in Canada. (6th ed.). Toronto: Between the Lines Press.

Carroll, W.K. \& Ratner, R.S. (2001). Sustaining oppositional cultures in 'post-socialist' times: A comparative study of three social movement organizations. Sociology, 35, 3, 605-629.

Carter, H.G. \& Crawshaw, F.M. (1929). Tudor on charities: A practical treatise on the law relating to gifts and trusts for charitable purposes, $5^{\text {th }}$ Ed. London: Sweet \& Maxwell. 


\section{Mulé (2011)}

Charity Commission for England and Wales (CCEW). (2005). RR12 - The Promotion of Human Rights. URL:

http://www.charity-commission.gov.uk/publications/rr12.aspx\#21 [March 6, 2007].

Charity Commission for England and Wales (CCEW). (2002a). CC9 - Political Activities and Campaigning by Charities. URL: http://www.charity-commission.gov.uk/publications/cc9.asp [July 16, 2002].

Charity Commission for England and Wales (CCEW). (2003a). Frequently Asked Questions - Registering A Charity. URL: http://www.charity-commission.gov.uk/registration/faqpage.asp [November 6, 2003].

Charity Commission for England and Wales (CCEW). (2003b). Promotion of Equality and Diversity for the Benefit of the Public. URL: http://www.charity-commission.gov.uk/registeredcharities/ped.asp [October 14, 2003].

Charity Commission for England and Wales (CCEW). (2002b). The Promotion of Human Rights. URL: http://www.charitycommission.gov.uk/registeredcharities/promhr.asp [September 17, 2002].

Charity Commission News. (December 2006). Charity Commission celebrates new Charities Act. Charity Commission for England and Wales: Charities Act 2006 News Updates. URL: http://www.charity-commission.gov.uk/news/charbillnews.asp [March 6, 2007].

Charity Commission News. (2003). Fair play for charity. Charity Commission for England and Wales. Issue 19. URL: http://www.charity-commission.gov.uk/tcc/ccnews19.asp [November 28, 2003].

Charity Lobbying in the Public Interest (CLPI). (2002a). Basic Information about the 1976 Law Governing Lobbying and Charities. URL: http://www.clpi.org/doc_pdf/lobbying_is_legal.pdf [December 3, 2002].

Charity Lobbying in the Public Interest (CLPI). (2008b). Important Lobbying Exclusions from the 1976 Law. URL: http://www.clpi.org/images/pdf/Exclusions\%20from\%20Lobbying\%20Color.qxp.pdf [November 6, 2010].

Charity Lobbying in the Public Interest (CLPI). (2002c). Lobbying and Advocacy - Similarities and Differences. URL: http://www.clpi.org/doc_pdf/what_is_lobbying.pdf [December 3, 2002].

Charity Lobbying in the Public Interest (CLPI). (2002d). Understanding the Differences Between Direct Lobbying and Grassroots Lobbying. URL:http://www.clpi.org/legal_defs.html [December 3, 2002].

Coalition for Lesbian and Gay Rights in Ontario. (2003). Consultation Response: Registered Charities - Political Activities/Registered Charities that Focus on Eliminating Racial Discrimination. Toronto: CLGRO.

Cotterrell, R.B.M. (1975). Charity and politics. The Modern Law Review, 38(4), 471-474.

Dominelli, L. (1997). Sociology of Social Work. London: MacMillan Press.

Dominelli, L. (2002). Anti-Oppressive Social Work Theory and Practice. Basingstoke: Palgrave MacMillan.

Drassinower, A. (2001). "The doctrine of political purposes in the law of charities: A conceptual analysis." In J. Phillips, B. Chapman \& D. Stevens (Eds.) Between state and market: Essays on charity law and policy in Canada, (288-308). Kingston: McGill-Queens University Press.

Duggan, L. (2003) The Twilight of Equality?: Neoliberalism, Cultural Politics, and the Attack on Democracy. Boston: Beacon Press.

Dunn, A. (1996). Charity law - a political scandal? Web Journal of Current Legal Issues. URL: http://webicli.ncl.ac.uk/1996/issue2/dunn2.htm|\#bk13 [November 16, 2002].

Dunn A. (2008). Charities and Restrictions on Political Activities: Developments by the Charity Commission for England and Wales in Determining the Regulatory Barriers. International Journal of Not-for-Profit Law, 11, 1. URL:

http://www.icnl.org/knowledge/ijn//vol11iss1/special_3.htm [November 27, 2010]. 


\section{Mulé (2011)}

EGALE Canada. (2003). Rainbow Visions Conference. Montréal, Quebec.

Elson, P. (2007) A Short History of Voluntary Sector-Government Relations in Canada The Philanthropist 21, 1, 36-74.

Elson, P.R. (2007/2008 Fall/Winter) Where is the voice of Canada's voluntary sector? Canadian Review of Social Policy, 60/61,1-20.

Fook, J. (1993). Radical Case Work: A Theory of Practice. St. Leanard's: Allen \& Unwin.

Fook, J. (2002). Social Work: Critical Theory and Practice. London: Sage.

Fridman, G.H.L. (1953). Charities and public benefit. Canadian Bar Review, 31, 537.

Gladstone, F. (1982). Charity, law and social justice. London: Bedford Square Press.

Good, D.A. (2003). Promises and pitfalls: Experience in collaboration between the Canadian federal government and the voluntary sector. Journal of Policy Analysis and Management, 22(1), 122-127.

Hall, M.H., de Wit, M.L., Lasby, D., Mclver, D., Evers, T., Johnston, C., et al. (2005). Cornerstones of community: Highlights of the national survey on non-profit and voluntary organizations (2003 revised). Ottawa: Statistics Canada.

Harvie, B.A. (2002). Regulation of advocacy in the voluntary sector: Current challenges and some responses. Voluntary Sector Secretariat, Voluntary Sector Initiative. URL: http://www.vsi-isbc.org/eng/policy/pdf/regulation_of_advocacy.pdf [November 20, 2010].

Healy, K. (2000). Social Work Practices: Contemporary Perspectives in Change. London: Sage.

Human Resources and Skills Development Canada (HRSDC). (2009). Voluntary Sector Initiative Impact Evaluation: Lessons Learned from the Voluntary Sector Initiative (2000 - 2005). Ottawa, HRSDC: Strategic Policy and Research Branch. URL: http://www.hrsdc.gc.ca/eng/publications_resources/evaluation/2009/sp_946_04_10e/sp_946_04_10_eng.pdf [November 4, 2010].

Ilcan , S. \& Basok, T. (2004). Community government: Voluntary agencies, social justice, and the responsibilization of citizens. Citizenship Studies, 8(2), 129-144.

Institute for Media, Policy and Civil Society (IMPACS) and the Canadian Centre for Philanthropy (CCP). (2002). Let Charities Speak: Report of the Charities and Advocacy Dialogue. Vancouver, Toronto: IMPACS.

Institute for Media, Policy and Civil Society (IMPACS). (2001a). Charities and Advocacy Project. Vancouver: IMPACS.

Institute for Media, Policy and Civil Society (IMPACS). (2001b). The Law of Advocacy by Charitable Organizations: Options for Change. Vancouver: IMPACS.

Institute for Media, Policy and Civil Society (IMPACS). (2001c). The Law on Charities and Advocacy. Toronto: IMPACS.

Internal Revenue Service (IRS). (2002). Charities \& Non-Profits. URL: http://www.irs.gov/charities/article/0,id=96099,00.html [November 26, 2002].

Internal Revenue Service (IRS). (2009). Exempt Purposes - Internal Revenue Code Section 501(c)(3). URL:

http://www.irs.gov/charities/charitable/article/0, id=175418,00.html [November 6, 2010].

International Lesbian and Gay Association. (ILGA) (2000). World Legal Survey. URL: http://www.ilga.org/Information/legal_survey/americas/Canada.htm [July 12, 2003].

Jensen, J. \& Phillips, S. (1996). Regime shifts: New citizenship practices of Canada. International Journal of Canadian Studies, 14, 111-136. 


\section{Mulé (2011)}

Jensen, J. (1993). All the world's a stage: Ideas, spaces and time in Canadian political economy. In

Jenson, J., Mahon, R. \& Bienefeld, M. (Eds.) Production, Space, Identity: Political Economy Faces the 21st Century, (pp. 143170). Toronto: Canadian Scholars' Press.

Jensen, J. (1995). Mapping, naming and remembering: Globalization at the end of the $21^{\text {st }}$ century. Review of International Political Economy, 2(1), 96-116.

Kinsman, G. (1987). The Regulation of Desire: Sexuality in Canada. Montréal: Black Rose Books.

Kinsman, G. (2006). Mapping social relations of struggle: Activism, ethnography, social organization. In Caelie Frampton, Gary Kinsman, A.K. Thompson \& Kate Tilleczek (Eds.) Sociology for changing the world: Social movements/social research, (pp. 133-156). Halifax: Fernwood Publishing.

Kymlicka, W. (1996). Three forms of group-differentiated citizenship in Canada. In Benhabib, S. (Ed.) Democracy and Difference: Contesting the Boundaries of the Political. (pp. 153-170). Princeton, NJ: Princeton University Press.

Laforest, R. \& Orsini, M. (2005). Evidence-based engagement in the voluntary sector: Lessons from Canada. Social Policy \& Administration. 39, 5, 481-497.

Laforest, R. \& Phillips, S. (2001). Rethinking the relationship between the government and the voluntary sector: A turning point for Québec and Canada. Politique et sociétés, 20(2-3), 37-68.

Lindsay, I. (2001). The voluntary sector. In Crick, B. (Ed.) Citizens: Towards a Citizenship Culture. (pp. 115-122). Oxford: Blackwell Publishers.

Malloy, J. (1999). What makes a state advocacy structure effective? Conflicts between bureaucratic and social movement criteria. Governance: An International Journal of Policy and Administration, 12(3), 267-288.

Michell, P. (1995). The political purposes doctrine in Canadian charities law. The Philanthropist, 12(4), 3-32.

Moreau, M.J. (1979). A structural approach to social work practice. Canadian Journal of Social Work Education, 5(1), 78-94.

Moreau, M.J. (1990). Empowerment through advocacy and consciousness-raising: Implications of a structural approach to social work. Journal of Sociology and Social Welfare, 17(2), 53-68.

Moreau, M.J. \& Leonard, L. (1989). Empowerment through a structural approach to social work. Ottawa: Carleton University.

Mulé, N.J. (2005). Beyond Words in Health and Wellbeing Policy: 'Sexual Orientation' - From Inclusion to Infusion, Canadian Review of Social Policy, 55, pp. 79-98.

Mulé, N.J. (2006). Equality's limitations, liberation's challenges: Considerations for queer movement strategizing", Canadian Online Journal of Queer Studies in Education, 2(1). http://jastudies.oise.utoronto.ca/journal/viewarticle.php?id=26 .

Mulé, N.J. (2007). "Sexual Orientation Discrimination in Health Care and Social Service Policy: A Comparative Analysis of Canada, the UK and USA" in L. Badgett and J. Frank, (Eds). Sexual Orientation Discrimination: An International Perspective. (pp. 306 - 322). New York: Routledge.

Mulé, N.J. (2008) Demarcating Gender and Sexual Diversity on the Structural Landscape of Social Work, Critical Social Work, 9(1). URL: http://www.criticalsocialwork.com/units/socialwork/critical.nsf/982f0e5f06b5c9a285256d6e006cff78 lebb5ace61ebf5d368525744c00802bdf?OpenDocument.

Mullaly, B. (2002). Challenging oppression: A critical social work approach. Don Mills: Oxford University Press. 


\section{Mulé (2011)}

Mullaly, R. (2006, September 29). Keynote Address. Structural social work: Honouring our past, considering our present, envisioning our future conference. Toronto: Ryerson University.

Mullaly, B. (2007). The new structural social work. Don Mills: Oxford University Press.

Mullaly, R. (1998). Structural Social Work: Ideology, Theory and Practice. (2nd Ed.) Toronto: Oxford University Press.

O'Connell, B. (1996). A major transfer of government responsibility to voluntary organizations? Proceed with caution. Public Administration Review, 56, 222-225.

Office for Civil Rights, Department of Health and Human Services. (August, 1990). Fact Sheet: Know Your Civil Rights. Washington, D.C.: Office for Civil Rights.

Ontario Law Reform Commission. (1996). Report on the law of charities. Toronto: Ontario. URL: http://www.mtroyal.ca/wcm/groups/public/documents/pdf/npr03_lawcharities.pd [November 16, 2010].

Panel on Accountability and Governance in the Voluntary Sector. (1999). Building on Strength: Improving Governance and Accountability in Canada's Voluntary Sector. Final Report. Ottawa.

Parachin, A. (2008). Distinguishing charity and politics: The judicial thinking behind the doctrine of political purposes. Alberta Law Review, 45(4), 871-899.

Pease, B. \& Fook, J. (1999). Transforming Social Work Practice: Postmodern Critical Perspectives. London: Routledge.

Phillips, A. (1996). Dealing with difference: A politics of ideas, or a politics of presence? In Benhabib, S. (Ed.) Democracy and Difference: Contesting the Boundaries of the Political, (pp. 139-152). Princeton, NJ: Princeton University Press.

Phillips, S. \& Levasseur, K. (2004). The snakes and ladders of accountability: Contradictions between contracting and collaboration for Canada's voluntary sector. Canadian Public Administration, 47(4), 451-474.

Phillips, S.D. (2003a). In accordance: Canada's voluntary sector accord from ideal to implementation. In K. Brock (Ed.) Delicate dances: Public policy and the non-profit sector, (pp. 17-62). Montreal \& Kingston: School of Policy Studies, Queen's University.

Phillips, S.D. (2003b). Voluntary sector - government relationships in transition: Learning from international experience for the Canadian context in Brock, K.L. \& Banting, K.G. (Eds.) The Nonprofit Sector in Interesting Times, (pp. 17-70). Montréal \& Kingston: McGill - Queen's University Press.

Phillips, S.D. (2004). The limits of horizontal governance: Voluntary sector - government collaboration in Canada. Society and Economy, 26(2-3), 393-415.

Phillips, S.D. (2010). Canada: Civic society under neglect. The Philanthropist, 23(1), p. 65-73.

Pross, A.P. (1986). Group Politics and Public Policy. Toronto: Oxford University Press.

Pross, A.P. \& Webb, K. (2003). Embedded regulation: Advocacy and the federal regulation of public interest groups. In K. Brock (Ed.) Delicate dances: Public policy and the non-profit sector. Montreal \& Kingston: School of Policy Studies, Queen's University.

Queer Ontario. (2010). Issues. URL: http://www.queerontario.org/issues [July 20, 2010].

Rayside, D. (1998). On the Fringe: Gays and Lesbians in Politics. Ithaca and London: Cornell University Press.

Richardson, D. (2005) 'Desiring Sameness? The Rise of a Neoliberal Politics of Normalisation. Antipode, 37(3): 515-535.

Ross, B.L. (1995). The House that Jill Built: A Lesbian Nation in Formation. Toronto: University of Toronto Press. 


\section{Mulé (2011)}

Sacks, A.M. (1960). The role of philanthropy: An institutional view. Virginia Law Review, 46, 516.

Scott, K. (2003). Funding matters: The impact of Canada's new funding regime on non-profit and voluntary organizations. Ottawa: Canadian Council on Social Development.

Sears, A. (2005). Queer anti-capitalism: What's left of lesbian and gay liberation? Science \& Society, 69(1), 92-112.

Sheridan, L.A. (1973). Charity versus politics. Anglo-American Law Review, 2, 47-68.

Smith, M. (1999). Lesbian and Gay Rights in Canada: Social Movements and Equality -Seeking, 1971-1995. Toronto: University of Toronto.

Smith, M. (2005a). Diversity and identity in the non-profit sector: Lessons from LGBT organizing in Toronto. Social Policy and Administration, 39(5), 463-480.

Smith, M. (2005b). Resisting and reinforcing neoliberalism: Lesbian and gay organizing at the federal and local levels in Canada. Policy \& Politics, 33(1), 75-94.

The Guardian. (November 26, 2003). Q\&A: the draft charities bill by Tash Shifrin. URL:

http://society.guardian.co.uk/charityreform/story/0,11494,1093603,00.html [December 6, 2003].

The Guardian. (September 11, 2002). Charity reform: the issue explained by Nicola Hill. URL: http://society.guardian.co.uk/Print/0,3858,4332120,00.html [October 4, 2002].

Trades Union Congress (TUC). (June 30, 2003). TUC Welcomes New Rights for Same Sex Couples. URL: http://www.tuc.org.uk/equality/tuc-6800-f0.cfm [July 11, 2003].

United Kingdom (UK) Government. (2005). Charities and Trustee Investment (Scotland) Act 2005 - The Charity Test. URL: http://www.legislation.gov.uk/asp/2005/10/part/1/crossheading/the-charity-test [November 6, 2010].

United Kingdom (UK) Government. (2006). Charities Act 2006 - Meaning of "Charitable Purpose." URL: http://www.legislation.gov.uk/ukpga/2006/50/section/2 [November 6, 2010].

United Kingdom (UK) Government. (2008). Charities Act (Northern Ireland) 2008 - Meaning of "Charitable Purpose." URL: http://www.legislation.gov.uk/nia/2008/12/section/2 [November 6, 2010].

Vaid, U. (1995). Virtual Equality: The Mainstreaming of Gay and Lesbian Liberation. New York: Doubleday.

Voluntary Sector Initiative. (2001a). About the VSI. Ottawa, ON. URL: http://www.vsi-isbc.ca/eng/about.cfm [March 21, 2003].

Voluntary Sector Initiative. (2001b). An Accord Between the Government of Canada and the Voluntary Sector. Ottawa.

Voluntary Sector Initiative. (2002a). Joint Accord Table on the Voluntary Sector Initiative, A Code of Good Practice on Funding, Building on An Accord Between the Government of Canada and the Voluntary Sector. Ottawa.

Voluntary Sector Initiative. (2002b). Research Project on Visible Minority Communities in Canada. URL: http://www.vsiisbc.ca/eng/reference_groups/visible_minorities/index.cfm [March 21, 2003].

Voluntary Sector Initiative. (2002c). Working Group on Advocacy. URL: http://www.vsi-

isbc.ca/eng/working_groups/advocacy/index.cfm [March 21, 2003].

Voluntary Sector Initiative. (2003). Joint Regulatory Table - Final Report. URL: http://www.vsi-

isbc.org/eng/regulations/pdf/jir_final_report.pdf [November 4, 2010]. 


\section{Mulé (2011)}

Walzer, M. (1995). The civil society argument. In Beiner, R. (Ed.) Theorizing Citizenship, (pp. 153 174). New York: State University of New York Press.

Ward, O. (2010). Planned Parenthood gets silent treatment. Toronto Star, A1, A12.

Warner, M. (1999). The Trouble with Normal: Sexual Politics and the Ethics of Queer Life. Cambridge, MA: Harvard University Press.

Warner, T. (2002). Never Going Back: A History of Queer Activism in Canada. Toronto: University of Toronto.

Webb, K. (2000). Cinderella's slippers? The role of charitable tax status in financing Canadian interest groups. Vancouver, BC: SFU - UBC Centre for the Study of Government and Business.

Wright, C.A. (1937). Case and comment. Canadian Bar Review, 15, 566.

\section{About the author / L'auteur}

Nick J. Mule is an Associate Professor in the School of Social Work, York University, Toronto, Canada. Email: nickmule@yorku.ca 